\title{
THE PRESENCE OF BILOBAR TUMOR SHOULD BE CONSIDERED AS A NEW LIMIT FOR TRANSPLANTATION BEYOND THE MILAN CRITERIA?
}

\author{
A presença de tumor bilobar deve ser considerado novo limite para exclusão de transplante em \\ pacientes que excedem os critérios de Milão? \\ Raul Carlos WAHLE ${ }^{1}$, Adávio de Oliveira e SILVA ${ }^{1}$, Adriano Miziara GONZALEZ ${ }^{2}$, \\ Jorge Marcelo Padilla MANCERO², Marcelo Augusto Fontenelle RIBEIRO-JUNIOR. ${ }^{2}$, Francisco Leôncio DAZZI², \\ Renato Ferrari LETRINTA², Cristiane Maria de Freitas RIBEIRO3, Venâncio Avancini Ferreira ALVES ${ }^{4}$, \\ Evandro Sobrosa MELLO ${ }^{4}$, Luiz Augusto CARNEIRO D’ALBUQUERQUE ${ }^{5}$
}

From ${ }^{1}$ Department of Gastroenterology and Hepatology, ${ }^{2}$ Department of General and Transplantation Surgery, ${ }^{3}$ Department of Pathology, Hospital Beneficência Portuguesa de São Paulo; ${ }^{4}$ Department of Pathology, Hospital Alemão Oswaldo Cruz; ${ }^{5}$ Department of Gastroenterology, São Paulo University School of Medicine, São Paulo - SP, Brazil.

HEADINGS: Carcinoma, hepatocellular. Liver transplantation.

\section{Correspondence:}

Luiz Augusto Carneiro D'Albuquerque

e-mail: pg.cir.ap.digecolop@hcnet.usp.br

Fonte de financiamento: não há

Conflito de interesses: não há

Recebido para publicação: 03/07/2009

Aceito para publicação: 14/12/2009

DESCRITORES: Carcinoma hepatocelular. Transplante de fígado.
ABSTRACT - Background - An imprecise estimate of the tumor's aggressiveness of the hepatocellular carcinoma especially in transplanted patients beyond the Milan criteria has a poor outcome, although a more reliable criteria including microscopic vascular invasion is difficult to be established before transplantation. Aim - To examine a cohort of patients with hepatocellular carcinoma undergoing liver transplantation to evaluate the preoperative predicting factors for microscopic vascular invasion. Methods - A series of 46 consecutive cirrhotic patients with hepatocellular carcinoma undergoing transplantation based on Milan criteria or similar criteria in a single center were enrolled between 1993 and 2007. The survival was calculated using Kaplan-Meyer's method and a multivariate Cox regression was performed to evaluate survival and factors related to microscopic vascular invasion. Results - Multifocal tumors were present in 39\%. Microvascular invasion, tumor relapses and hepatocellular carcinoma beyond the Milan criteria were identified in 33\%, 13\% and 33\%, respectively. Overall 1-, 3-, and 5-year actuarial patient survival rates were $64 \%, 59 \%$ and $45 \%$ respectively. Patients who exceeded the Milan criteria had a higher incidence of microscopic vascular invasion and bilobar tumor compared to those who met the Milan criteria ( $53 \%$ vs. $23 \%$ and $80 \%$ vs. $19 \% ; p<0.05$, respectively). After multivariate analysis, the variable identified as independent risk factor for microscopic vascular invasion was the presence of bilobar tumor (hazard ratio, 3.67; 95\% confidence interval, 1.01 to 13.34; $p<0.05)$. Conclusions - The presence of a bilobar tumor is more frequent in hepatocellular carcinoma beyond the Milan criteria and it is an independent predictive factor of a high risk of microscopic vascular invasion. The presence of bilobar tumor in hepatocellular carcinoma beyond the Milan criteria could be used as selection criteria to estimate the risk of hepatocellular carcinoma recurrence, at least until large randomized studies becomes available.

RESUMO - Racional - A recidiva tumoral após o transplante de fígado para o carcinoma hepatocelular tem grande impacto desfavorável na mortalidade e a presença de invasão microvascular desempenha papel importante na recidiva tumoral. Objetivo - Avaliar a sobrevida, o risco de recidiva tumoral pós-transplante e os fatores relacionados à invasão microvascular de uma série de transplantados por carcinoma hepatocelular. Métodos - No período entre 1993 e 2007 foi estudada uma série consecutiva de 46 cirróticos com carcinoma hepatocelular submetidos à transplante de fígado baseado nos critérios de Milão a partir de 1996 ou critérios semelhantes no período anterior a esta data. Inicialmente todas as variáveis foram analisadas descritivamente, e as quantitativas através da observação dos valores mínimos e máximos, e do cálculo de médias e desvios-padrão e medianas. Para as variáveis qualitativas calcularam-se frequências absolutas e relativas. Realizou-se a regressão logística com ajuste pelo modelo de Cox para avaliar a sobrevida e os fatores relacionados à recidiva tumoral e invasão microvascular. Resultados - A sobrevida da amostra foi de 64\%, 59\% e 45\% para 1, 3 e 5 anos, respectivamente. Em 13\% dos casos, a recidiva tumoral foi verificada. A análise multivariada identificou a chance de um paciente com nódulo bilobar sofrer invasão microvascular é 3,67 vezes maior em relação a um paciente com nódulo unilobar e a presença de um tumor unilobar representar um significativo efeito protetor em relação à invasão microvascular $(p=0,048)$. Conclusões - $A$ identificação de um tumor bilobar no estadiamento tumoral é fator preditivo independente de maior risco de invasão microvascular e é necessário ainda confirmar se a presença de tumor bilobar deve ser adicionada aos critérios de Milão para melhor indicação de transplante de fígado em pacientes cirróticos com carcinoma hepatocelular. 
INTRODUCTION

T he advent of liver transplantation has changed the therapeutic approach of hepatocellular carcinoma (HCC), once, in well-selected patients, such treatment can potentially cure the tumor and the underlying cirrhosis. In 1996, Mazzaferro established that the Milan criteria was the best indication for liver transplantation (LT) in HCC patients with a single lesion of up to $5 \mathrm{~cm}$ or 3 tumors of up to $3 \mathrm{~cm}$, without associated vascular invasion ${ }^{14}$. Such data were confirmed in later studies and adopted as a prioritization tool in the United Network of Organ Sharing (UNOS).

In recent years, several groups have proposed to extend the criteria with the aim of increasing the pool of patients enrolled for $\mathrm{LT}^{9,23,24}$. However, many reports demonstrate that tumor size and number have only a limited capacity to predict outcome after LT, and more sophisticated pre-operative predictors of tumor biology are urgently needed. The presence of microvascular invasion seems to be one of most important predictors of tumor recurrence after $\mathrm{LT}^{1,7,16,18}$. However, microscopic vascular invasion cannot be well determined before resection or transplantation ${ }^{3}$.

The aim of this study was to evaluate preoperative predicting factors for microvascular invasion in HCC patients undergoing LT.

METHODS

The sample in this retrospective study gathered 46 patients from authors transplantation center in Brazil, during the period from August 1993 to July 2007, with HCC confirmed by the histological analysis of explanted liver. Pre and post-operative clinicallaboratorial data were collected to determine survival and of tumor recurrence rate. The criteria for indication of transplantation were adapted to the Milan criteria. Between 1993 and 1996, the selection of candidates followed similar criteria adopted by the transplanting units. Thirty-one selected patients (67\%) met the Milan criteria, two patients met the University of California at San Francisco criteria, however, 13 patients (28\%) had tumor beyond this one. Patients were eligible to orthotopic transplantation (52\%), split (2\%) or living donor transplantation (46\%).

\section{Variables analyzed and statistic}

The variables analyzed were: age, sex, etiology of cirrhosis, Child-Pugh and MELD scores and tumor characteristics (presence of microscopic invasion, size, location, number of nodules and degree of tumor differentiation), post-operative survival, cause of death, and tumor recurrence. Microvascular invasion was defined by the presence of microscopic signs of invasion in the explanted. Post-transplant immunosuppression was similar. The degree of tumor differentiation was based on the classification of Edmonson and Steiner ${ }^{21}$. Global survival included all the post-transplantation deaths due to any cause and was classified as short term ( $<2$ years) and long term ( $\geq 2$ years). Patients were followed until their death or until the closing of the study in October 2008, resulting in at least 12 months of post-transplantation follow-up of all patients.

The categorical variables were analyzed by Fisher exact test. Survival was calculated using the Kaplan-Meyer method, with statistical significance determinate by the log-rank test. Univariate Cox model were fit individually for each of the possible predictors of survival. Logistic regression analysis, using Cox's proportion hazard model was performed. Results are reported as odds ratios (OR) and 95\% confidence intervals. A P-value $<0.05$ was considered significant. The statistic program $R$ version 2.7.2 of the R Foundation for Statistical Computing ${ }^{\circledR}$ was used for the purpose of statistic analysis.

\section{RESULTS}

Out of the 268 liver transplantations in adults conducted by the authors from August 1993 to July 2007, 46 patients (17\%) had HCC and were included in the study. The demographic data of the transplanted patients are shown in Table 1.

TABLE 1 - Population description

\begin{tabular}{|c|c|}
\hline Age (years) & $55.6 \pm 7.8$ (range, 42-70) \\
\hline Male sex & $41(89.2 \%)$ \\
\hline \multicolumn{2}{|l|}{ Pretransplantation indication } \\
\hline HCV-liver cirrhosis + HCC & 31 \\
\hline HBV-liver cirrhosis + HCC & 5 \\
\hline NASH-liver cirrhosis + HCC & 3 \\
\hline HH-liver cirrhosis + HCC & 3 \\
\hline Others ethiologies & 4 \\
\hline \multicolumn{2}{|l|}{ Child-Pugh stage } \\
\hline A & $21(46.6 \%)$ \\
\hline $\mathrm{B} / \mathrm{C}$ & $25(54.4 \%)$ \\
\hline \multicolumn{2}{|l|}{ MELD score } \\
\hline$\leq 10$ & $11(23.9 \%)$ \\
\hline $11-19$ & $30(65.2 \%)$ \\
\hline$\geq 20$ & $5 \quad(10.9 \%)$ \\
\hline \multicolumn{2}{|l|}{ Esophageal varices } \\
\hline Absent & $8(17.4 \%)$ \\
\hline Fine caliber & $19(41.3 \%)$ \\
\hline Medium or large caliber & $19(41.3 \%)$ \\
\hline \multicolumn{2}{|l|}{ Ascites } \\
\hline Absent & $21(46.7 \%)$ \\
\hline Grade 1-2 & $13(28.3 \%)$ \\
\hline Grade 3 or refractory & $12(26 \%)$ \\
\hline Serum level of AFP> $200 \mathrm{ng} / \mathrm{mL}$ & $9(19.5 \%)$ \\
\hline Median level of AFP & $13.75 \mathrm{ng} / \mathrm{mL}$ \\
\hline
\end{tabular}

Abbreviations: HBV, hepatitis B virus; HCV, hepatitis C virus; NASH, non-alcoholic steatohepatitis; $\mathrm{HH}$, hereditary hemochromatosis, AFP (alpha-fetoprotein).

Of the 46 patients, 41 were male and mean age at time of transplantation was 56 years. The mean tumor size was $3.2 \pm 2.1 \mathrm{~cm}$. Multifocal HCC was present in $39 \%$. 
Microvascular invasion, tumor relapse and HCC beyond the Milan criteria were identified in 33\%, $13 \%$ and $33 \%$, respectively. Six patients (13\%) had tumor relapse, in 3 patients presented tumor recurrence in the graft in the first year of follow-up. There were five deaths related to tumor relapse and one of the patients with bone metastasis is still alive after four years of follow-up.

During the post-operative, $60 \%$ of deaths occurred in the first month after $L T(n=12)$ and were related to infective complications, variceal upper gastrointestinal bleeding, primary dysfunction of the graft and acute rejection. The global survival in the first year after transplantation was $64 \%$, reaching $59 \%$ and $45 \%$ in the third and fifty year respectively (Figure 1).

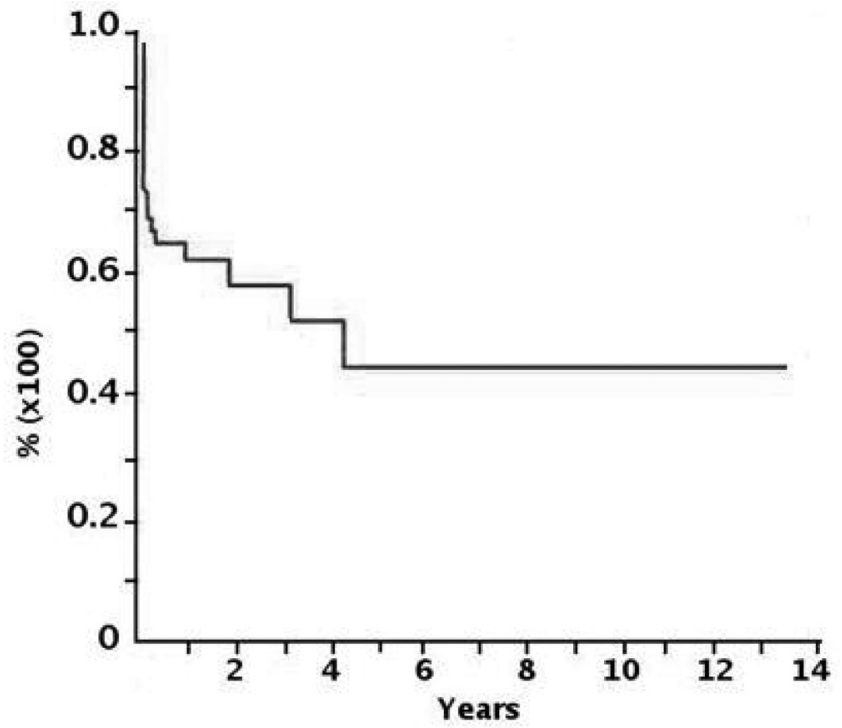

FIGURE 1 - Actuarial survival of HCC patients after liver transplantation

Table 2 summarizes the outcome and pathological features of patients meeting Milan criteria compared to those outside Milan criteria. Microvascular invasion was more common among patients outside Milan criteria. There was no significant difference in mean age, gender or others clinical features between the two groups. There was a lower survival among patients with recurrent HCC especially after first year post liver transplant (Figure 2).

TABLE 2 - Outcome and pathologic features of patients meeting Milan criteria compared to those outside Milan criteria

\begin{tabular}{lccc}
\hline Patient group & \multicolumn{1}{c}{ A } & B & \multirow{2}{*}{ A vs. B (P) } \\
\cline { 2 - 3 } & Milan $(n=31)$ & Beyond Milan $(n=15)$ & NS \\
\hline Recurrence (\%) & $4(13)$ & $2(13)$ & 0.04 \\
$\begin{array}{l}\text { Microvascular } \\
\text { invasion (\%) }\end{array}$ & $7(23)$ & $8(53)$ & NS \\
\hline $\begin{array}{l}\text { Mean follow-up } \\
\text { [year (range)] }\end{array}$ & $4(2-14)$ & $3(2-9)$ & \\
\hline
\end{tabular}

Abbreviation: NS, not statistically significant $(P>0.05)$.

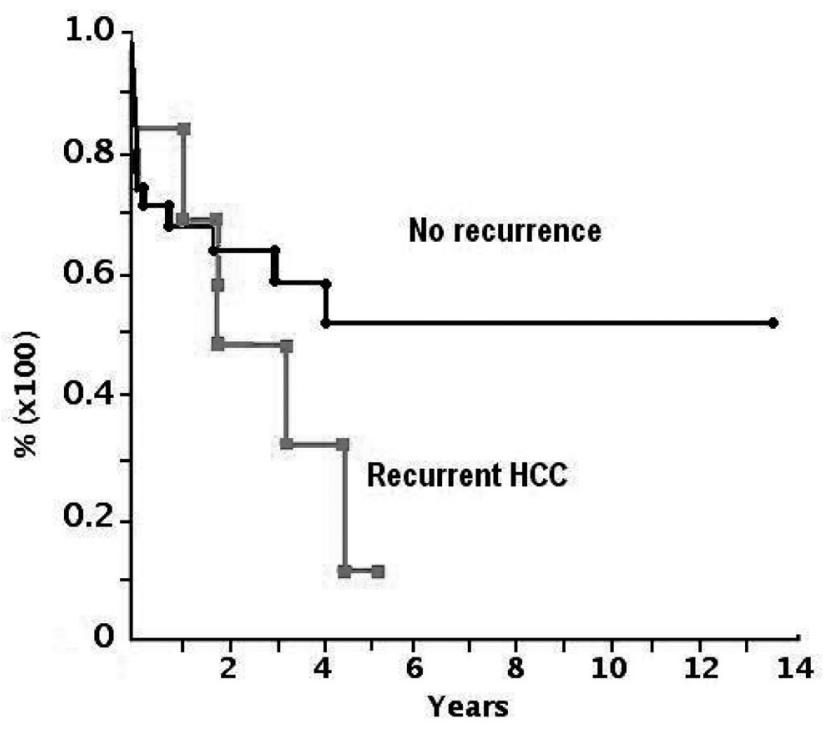

FIGURE 2 - Actuarial survival of patients with recurrent HCC after liver transplantation compared to those without recurrence

Table 3 summarizes a univariate analysis of pathological features in patients with $\mathrm{HCC}$, as predictors of long-term survival after LT. Despite of presence of unilobar tumor was more frequent in patients within Milan criteria no significant difference was observed as a factor related to long term of survival after LT.

TABLE 3 - Pathologic features of patients with HCC as predictors of long-term survival after liver transplantation

\begin{tabular}{|c|c|c|c|}
\hline Pathologic tumor feature ${ }^{1}$ & $\mathrm{P}$ & OR & $95 \% \mathrm{CI}$ \\
\hline $\begin{array}{l}\text { Number of nodules } \leq 3 \mathrm{~cm} \\
(\mathrm{vs} .>3 \mathrm{~cm})(\mathrm{n}=35)\end{array}$ & 0.03 & 10.07 & $1.26-81.3$ \\
\hline $\begin{array}{l}\text { Size of largest tumor }<5 \mathrm{~cm} \\
(\mathrm{vs} .>5 \mathrm{~cm})(\mathrm{n}=39)\end{array}$ & 0.01 & 14.15 & $1.79-112.27$ \\
\hline $\begin{array}{l}\text { Unilobar tumor } \\
\text { (vs. bilobar) }(n=28)\end{array}$ & 0.05 & 5.99 & $0.95-37.74$ \\
\hline
\end{tabular}

Note: ${ }^{1}$ Analysis of pathological features was performed with Cox models. Abbreviation: $\mathrm{CI}$, confidence interval.

To identify predictors of microvascular invasion in patients with HCC, a separate analysis was performed with Cox models. On univariate analysis, high histological grade (grades III-IV) and presence of bilobar tumor were associated with the presence of microvascular invasion in explanted liver. The rates of bilobar tumors in patients meeting Milan criteria and beyond the Milan criteria are shown in Figure 3. The global incidence of bilobar tumor was $39 \%$. Patients who exceeded Milan criteria had a higher incidence of bilobar tumor compared to those who met Milan criteria ( $80 \%$ vs. $19 \%$; $P<0.05)$.

On multivariate analysis, only bilobar tumor remained independent predictor of microvascular invasion (Table 4). After the adjustment for the logistic regression for risk of microvascular invasion showed a significant protective effect related to the location of the tumor was observed $(P=0.048)$ and the chance of 
a patient with a bilobar nodule suffering microvascular invasion was 3.67 times higher than that of a patient with a unilobar nodule (confidence interval $=1.01-13.34$ ).

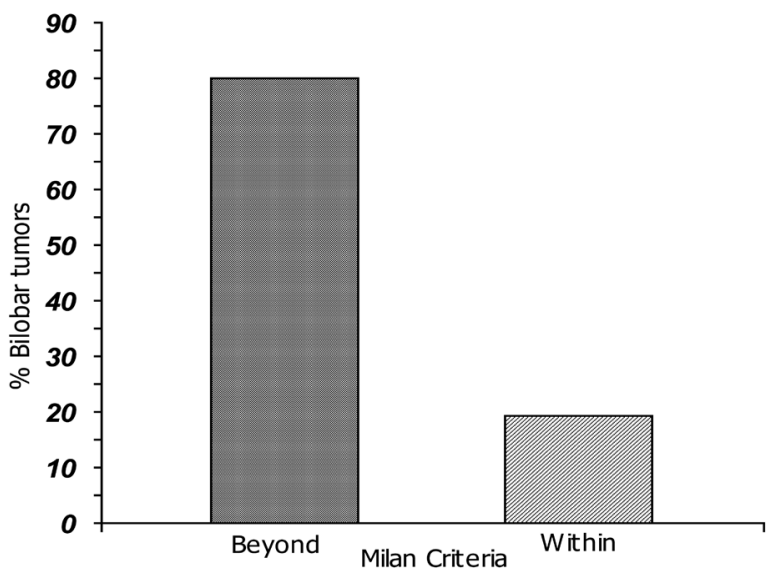

FIGURE 3 - The incidence of bilobar tumor in patients with $\mathrm{HCC}$ within and beyond the Milan criteria

\section{DISCUSSION}

This publication presents high early mortality, which may be related to the use of marginal donors, in patients with severe illness and acutely treated against the underlying disease and tumor, where a critical patient is compensated with hospital support and in the expectation of cure, a marginal liver is accepted. It must be pointed out that in Brazil, the change of criteria for organ allocation based on MELD severity criteria and the priority for organ allocation for patients who have HCC was implemented in May 2006, and the majority of our patients (74\%) was transplanted before this prioritization tool, when the criterion for allocation was chronological, and patients waited in list more than two years. In order to surpass the previous limitation imposed by the public policy for organ allocation and the reduced offer of cadaveric donors, this group of authors started to practice the modality of living donor transplantation and there have been 21 surgeries involving living donors (46\%) in this series.

The lack of consensus on expanded indications for $\mathrm{HCC}$ remains the same and the most important question to be answered is whether expanded criteria can result in acceptable post-transplant survival considering the donor-recipient disparity. Several factors have been related to a greater chance of tumor recurrence after LT such as size, number of tumors, presence of vascular invasion, poorly differentiated tumor ${ }^{2,6,17}$. Once the presence of microvascular invasion can only be well determined by histological analysis of the explanted liver, it is essential to identify the pre-operative factors capable of being correlated to such condition, for a better selection of HCC patients eligible to LT.

A greater predominance of elevated alphafetoprotein (AFP) blood levels in patients with microvascular invasion was noticed in this study; however, in the multivariate analysis, AFP level was not established as an independent variable. Only $19.5 \%$ of the patients presented AFP levels higher than $200 \mu \mathrm{g} / \mathrm{L}$ with a similar distribution among the groups studied. In addition, a relationship between larger tumors and higher AFP levels was not seen, in spite of what was observed in the study by Nomura et al. ${ }^{15}$.

The size of the nodules has been considered by some authors as a way to predict relapse and survival ${ }^{5,19}$, yet in other groups as observed in your study, it has not been possible to establish this relationship, partly due to problems of sample size $e^{4,12}$.

The presence of a bilobar tumor presented an independent correlation to microvascular invasion in this study and other have also stated the presence of a bilobar tumor as a factor associated to a higher rate of post-transplant recurrence $\mathrm{e}^{8,11,20}$.

From the results here presented, it can be concluded that the degree of tumor differentiation was a variable that lack prognostic value. The low number of patients with poorly differentiated tumors (19\%) may be a reason that statistic significance was not reached.

In a recent study of Mazzaferro et al. ${ }^{13}$, microvascular invasion is strictly related to size-and-number covariates and tumor grading, and doubles the hazard of recurrence and death after LT. Another factor involved to this issue, is that, in spite of the improvement imaging techniques, about one third of the cases, HCC larger than $3 \mathrm{~mm}$ in explanted livers had been underestimated in pre-LT CT or $\mathrm{MRI}^{10,13}$. In Silva et al. ${ }^{22}$ paper, bilobar involvement and poor tumor differentiation were independent risk factors of radiological underestimation. Thus, histologic examination of HCC is desirable before LT as part of novel scoring systems to predict the risk of HCC recurrence. However, pre-LT fine-needle biopsy has been shown to poorly correlate with tumor grading and presence of microvascular invasion compared to surgical specimens ${ }^{3}$ and so far other caveats of tumor biopsy is the problem of tumor sampling error and the risk of tumor spread. Therefore, non-invasive methods to identify tumor microvascular invasion are urgently needed.

\section{CONCLUSION}

The presence of a bilobar tumor is an independent predictive factor for microvascular invasion and may be used as an exclusion criteria for LT especially in patients with HCC beyond the Milan criteria, at least large randomized studies becomes available.

\section{REFERENCES}

1. Chau GY, Lui WY, Wu CW. Spectrum and significance of microscopic vascular invasion in hepatocellular carcinoma. Surg Oncol Clin N Am 2003;12 (1):25-34.

2. Edmondson HA, Steiner PE. Primary carcinoma of the liver: A study of 100 cases among 48,900 necropsies. Cancer 1954;7:462-503. 
3. Esnaola NF, Lauwers GY, Mirza NQ, Nagorney DM, Doherty $D_{\text {, }}$ Ikai I, Yamaoka Y, Regimbeau JM, Belghiti J, Curley SA, Ellis LM, Vauthey JN. Predictors of microvascular invasion in patients with hepatocellular carcinoma who are candidates for orthotopic liver transplantation. J Gastrointest Surg 2002;6:224-32.

4. Frilling $A$, Malago $M$, Broelsch CE. Current status of liver transplantation for treatment of hepatocellular carcinoma. Dig Dis 2001;19(4): 333-37.

5. Grasso A, Stigliano R, Morisco F, Martines H, Quaglia A, Dhillon AP, Patch D, Davidson BR, Rolles K, Burroughs AK. Liver transplantation and recurrent hepatocellular carcinoma: predictive value of nodule size in a retrospective and explant study. Transplantation 2006:81:1532-41.

6. Herrero I, Sangro B, Quiroga J, Pardo F, Herraiz M, Cienfuegos $\mathrm{JA}$, Prieto J. Influence of tumor characteristics on the outcome of liver transplantation among patients with liver cirrhosis and hepatocellular carcinoma. Liver Transpl 2001;7:631-36.

7. Jonas $S$, Bechstein WO, Steinmüller T, Herrmann M, Radke $C$, Berg T, Settmacher U, Neuhaus P. Vascular invasion and histopathologic grading determine outcome after liver transplantation for hepatocellular carcinoma in cirrhosis. Hepatology 2001;33:1080-86.

8. Kotlyar DS, Campbell MS, Reddy KR. Recurrence of diseases following orthotopic liver transplantation. Am J Gastroenterol 2006;101:1370-78.

9. Lee HS. Liver transplantation for hepatocellular carcinoma beyond the Milan criteria: the controversies continue. Dig Dis 2007;25:296-98.

10. Marelli L, Grasso A, Pleguezuelo M, Martines H, Stigliano R, Dhillon AP, Patch D, Davidson BR, Sharma D, Rolles K, Burroughs AK. Tumour size and differentiation in predicting recurrence of hepatocellular carcinoma after liver transplantation: external validation of a new prognostic score. Ann Surg Oncol 2008;15: 3503-11.

11. Marsh JW, Dvorchik I, Subotin M, Balan V, Rakela J, Popechitelev EP, Subbotin V, Casavilla A, Carr BI, Fung JJ, Iwatsuki S. The prediction of risk of recurrence of hepatocellular carcinoma after orthotopic liver transplantation: A pilot study. Hepatology 1997;26:444-50.

12. Martínez Ares D, Suárez López FJ, Souto Ruzo J, Otero Ferreiro A, Gómez Gutiérrez M, González Conde B, Fernández Sellés C, Gala López B, Arnal Monreal F, Vázquez Iglesias JL. Liver transplantation in patients with hepatocellular carcinoma: factors implicated in tumor relapse. Rev Esp Enferm Dig 2004; 96:22-31.

13. Mazzaferro V, Llovet JM, Miceli R, Bhoori S, Schiavo M, Mariani L, Camerini T, Roayaie S, Schwartz ME, Grazi GL, Adam R, Neuhaus P, Salizzoni M, Bruix J, Forner A, De Carlis L, Cillo U, Burroughs AK, Troisi R, Rossi M, Gerunda GE, Lerut J, Belghiti J, Boin I, Gugenheim J, Rochling F, Van Hoek B, Majno P; Metroticket Investigator Study Group. Predicting survival after liver transplantation in patients with hepatocellular carcinoma beyond the Milan criteria: a retrospective, exploratory analysis. Lancet Oncol. 2009;10:35-43.
14. Mazzaferro V, Regalia E, Doci R, Andreola S, Pulvirenti A, Bozzetti F, Montalto F, Ammatuna M, Morabito A, Gennari L. Liver transplantation for the treatment of small hepatocellular carcinomas in patients with cirrhosis. N Engl J Med 1996;334:69399.

15. Nomura F, Ohnishi K, Tanabe Y. Clinical features and prognosis of hepatocellular carcinoma with reference to serum alphafetoprotein levels. Cancer 1989;64:1700-07.

16. Parfitt JR, Marotta P, Alghamdi M, Wall W, Khakhar A, Suskin NG, Quan D, McAllister V, Ghent C, Levstik M, McLean C, Chakrabarti S, Garcia B, Driman DK. Recurrent hepatocellular carcinoma after transplantation: use of a pathological score on explanted livers to predict recurrence. Liver Transpl 2007;13:543-51.

17. Pawlik TM, Gleisner AL, Anders RA, Assumpcao L, Maley W, Choti MA. Preoperative assessment of hepatocellular carcinoma tumor grade using needle biopsy: implications for transplant eligibility. Ann Surg. 2007; 245:435-42.

18. Pérez de Luque D, López Vallejos P, Montero Alvarez JL, Fraga Rivas E, Barrera Baena P, Costán Rodero G, Rufian Peña S, Díaz Iglesias C, López-Cillero P, Briceño Delgado J, Padillo Ruiz J, Pozo Laderas JC, Marchal Molina T, Solórzano Peck G, de la Mata García M. Survival of patients receiving a liver transplant for hepatocellular carcinoma, and risk of tumor recurrence. Rev Esp Enferm Dig 2006;98(12):899-906.

19. Roayaie S, Schwartz JD, Sung MW, Emre SH, Miller CM, Gondolesi GE, Krieger NR, Schwartz ME. Recurrence of hepatocellular carcinoma after liver transplant: patterns and prognosis. Liver Transpl 2004; 10 (4): 534-40.

20. Schwartz M. Liver transplantation in patients with hepatocellular carcinoma. Liver Transpl 2004;10:S81-85.

21. Shah SA, Tan JCC, McGilvray ID, Cattral MS, Levy GA, Greig PD, Grant DR. Does microvascular invasion affect outcomes after liver transplantation for HCC? A histopathological analysis of 155 consecutive explants. J Gastrointest Surg 2007;11:464-71.

22. Silva M, Moya A, Berenguer M, Sanjuan F, López-Andujar R, Pareja E, Torres-Quevedo R, Aguilera V, Montalva E, De Juan M, Mattos A, Prieto $M$, Mir J. Expanded criteria for liver transplantation in patients with cirrhosis and hepatocellular carcinoma. Liver Transpl 2008; 14:1449-60.

23. Soejima Y, Taketomi A, Yoshizumi T, Uchiyama H, Aishima S, Terashi T, Shimada M, Maehara Y. Extended indication for living donor liver transplantation in patients with hepatocellular carcinoma. Transplantation 2007;83:893-99

24. Yao FY, Ferrell L, Bass NM, Bacchetti P, Ascher NL, Roberts JP. Liver transplantation for hepatocellular carcinoma: comparison of the proposed UCSF criteria with the Milan criteria and the Pittsburgh modified TNM criteria. Liver Transpl 2002;8:765-74. 